\title{
LETTER
}

\section{Clinopyroxene-rich lherzolite xenoliths from Bir Ali, Yemen - possible product of peridotite/melt reactions}

\author{
Murad Ali and Shoji ARAI \\ Department of Earth Sciences, Kanazawa University, Kakuma-machi, Kanazawa 920-1192, Japan
}

\begin{abstract}
Ultramafic xenoliths in Pliocene-Quaternary basalts from Bir Ali, the Shabwa Governorate, southern Yemen, were studied to examine upper mantle processes related to continental rifting. They show a great variety of rock types: spinel lherzolites, harzburgites, dunites, clinopyroxene $(=\mathrm{cpx})$-rich lherzolites, wehrlites and pyroxenites. The cpx-rich lherzolites and wehrlites with high clinopyroxene/orthopyroxene ratios $(>1)$, which are characteristic of the Bir Ali xenolith suite, contain lower Fo contents of olivine than ordinary lherzolites at a given $\mathrm{Cr} \#$ of spinel. Their clinopyroxenes are higher in $\mathrm{TiO}_{2}$ and $\mathrm{REE}$ contents than those in the ordinary lherzolites, which are restite. These features strongly indicate metasomatic addition of clinopyroxene from alkali basalts at the expense of orthopyroxene to depleted peridotites for genesis of the $\mathrm{cpx}^{-}$-rich lherzolites. The cpxrich lherzolites are one of common constituents of lithospheric mantle at rifted continental margins.
\end{abstract}

Keywords: Xenoliths, Clinopyroxene-rich lherzolites, Metasomatism, Rifted continental margins, Bir Ali, Yemen

\section{INTRODUCTION}

Major mantle processes such as depletion and enrichment in melt components can be investigated via petrological studies of mantle-derived xenoliths (e.g., Griffin et al., 1999; Dawson, 2002; Chazot et al., 2005; Beard et al., 2006). Peridotite xenoliths from Plio-Quaternary basaltic volcanic fields along the south coast of Yemen (Bir Ali Area) are upper mantle materials beneath a young rifted continental margin and provide us with information concerning deep processes of continental break-up. They have been extensively studied mainly by European people (Chazot et al., 1996a, 1996b, 1997; Baker et al., 2002). Chazot and his co-workers made the first report on xenoliths from Bir Ali area and discussed mantle processes within the lithosphere beneath the Arabian Peninsula (Chazot et al., 1996a, 1996b, 1997). These mantle xenoliths are re-examined based on major and trace-element mineral chemical data combined with detailed petrographical descriptions. In this paper we highlight peculiar clinopyroxene-rich lherzolites or wehrlitic lherzolites that are characteristic of the Bir Ali xenolith suite. Such lherzolites have been reported from several localities. (e.g., Fabriès et al., 1988; Witt-Eickschen and Kramm, 1998; $\mathrm{Xu}$ et al., 2002), and their characteristics seem to be comdoi:10.2465/jmps.060826 M. Ali, muradali_74@yahoo.com Corresponding author mon in continental areas, although their petrological processes have not been thoroughly examined.

\section{GEOLOGICAL SETTING AND HOST ROCKS}

The Afar-Arabian rift system is one of the most extensive and active continental rift zones. The late Eocene to Recent volcanic sequences, believed to be related to the Afar mantle plume activities, are widely distributed in the Afar-Ethiopian province and south-western Arabian Peninsula (e.g., White and McKenzie, 1989) (Fig 1). The basaltic complex of Bir Ali volcanic field in Shabwa Governorate is located in the western part of the WSWNEN trending Gulf of Aden coastal uplift, and formed in the Pliocene to Quaternary (Fig. 1). It covers an area of $450 \mathrm{~km}^{2}$, and the whole complex forms two slightly rising shield-like elevations mounted by numerous volcano cones different in size and altitude. Most of the volcanoes consist of basaltic tuffs and scoria. Only a few flat eruptive cones situated in the north part are composed of basaltic lavas. Individual volcanoes are characterized by central type eruption. They are distributed along the coastal plain of the Gulf of Aden starting from Perim Island in the west to Bir Ali in the east. Mafic to ultramafic xenoliths, which are rarely coated with thin lava, are mainly enclosed by alkali olivine basaltic pyroclasties. The host is sparsely porphyritic, with less than $5 \mathrm{vol} \%$ of 


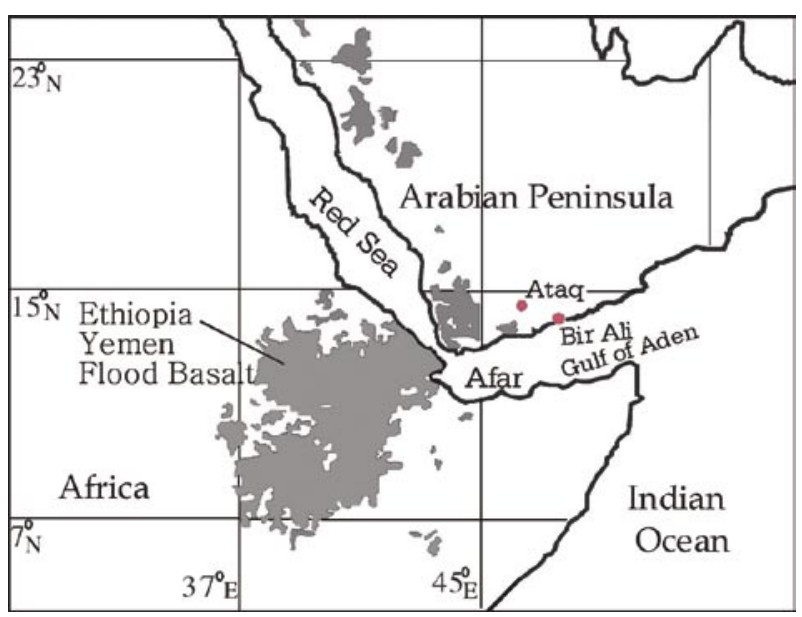

Figure 1. (A) Location of the Bir Ali area and distribution of Cenozoic flood basalts in the African-Arabian triple-junction area (modified after White and McKenzie, 1989).

phenocrysts of olivine and clinopyroxene. More than one hundred xenoliths up to $20 \mathrm{~cm}$ across were collected from the Karif Shworan alkali olivine basaltic pyroclastic cone (upper to recent Quaternary).

\section{PETROGRAGHY AND CLASSIFICATION OF MANTLE XENOLITHS}

We found anhydrous and hydrous lherzolites, spinel harzburgites, pyroxenite, dunites, wehrlites, granulites, and banded plagioclase peridotites as discrete xenoliths. Modal amounts of olivine, orthopyroxene and clinopyroxene in xenoliths were determined by point counting (Fig. 2). The mode is highly variable in terms of olivine, clinopyroxene and orthopyroxene contents (Fig. 2). They overall vary from dunites to websterites through lherzolites (Fig.

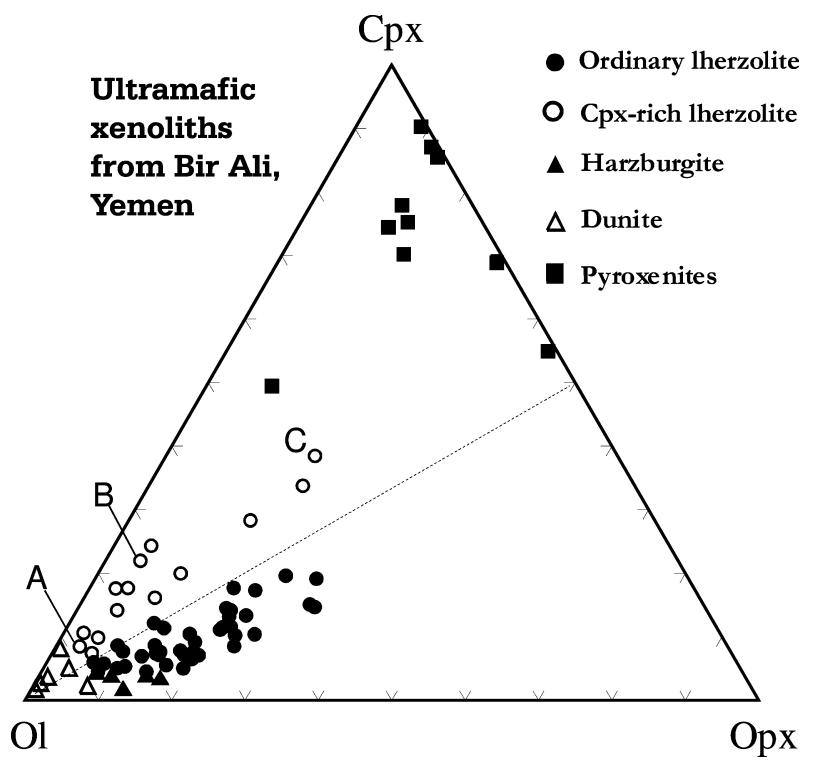

Figure 2. Modal amounts of olivine (Ol), orthopyroxene (Opx) and clinopyroxene (Cpx) of ultramafic xenoliths from Bir Ali, Yemen. Clinopyroxne-rich (cpx-rich) lherzolites are characteristic of the Bir Ali xenolith suite. For the typical three samples (A. $\mathrm{B}$ and $\mathrm{C})$, mineral chemical composition are listed and plotted (Figs. 5 and 6).

2). It is noteworthy that clinopyroxne-rich lherzolites and wehrlites are abundant in addition to ordinary lherzolites (Fig. 2). In this article we collectively call the lherzolites and wehrlites with clinopyroxene/orthpyroxene ratio higher than unity as "clinopyroxen-rich (cpx-rich) lherzolites".

Most of the ordinary lherzolites exhibit coarsegrained equigranular (equigranular mosaic and tabular) textures (Fig. 3A). Some show intermediate textures between protogranular and equigranular. Olivine grains show
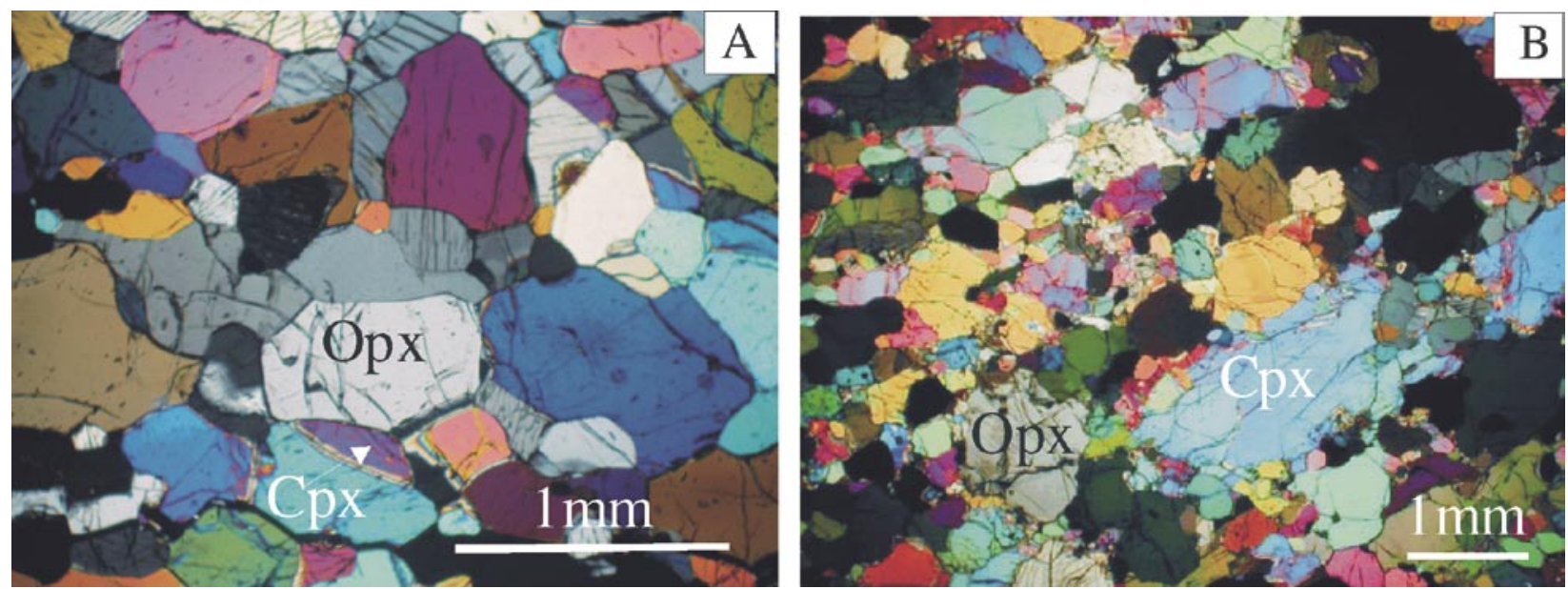

Figure 3. Photomicrographs of ultramafic xenoliths from Bir Ali, Yemen. XPL, crossed-polarized light. Abbreviations: Ol, olivine; Opx, orthopyroxene; Cpx, clinopyroxene. (A) Ordinary lherzolite. XPL. Clinopyroxenes are smaller in amount than orthopyroxenes. (B) Clinopyroxene-rich lherzolite with a high clinopyroxne/orthopyroxene ratio. XPL. 


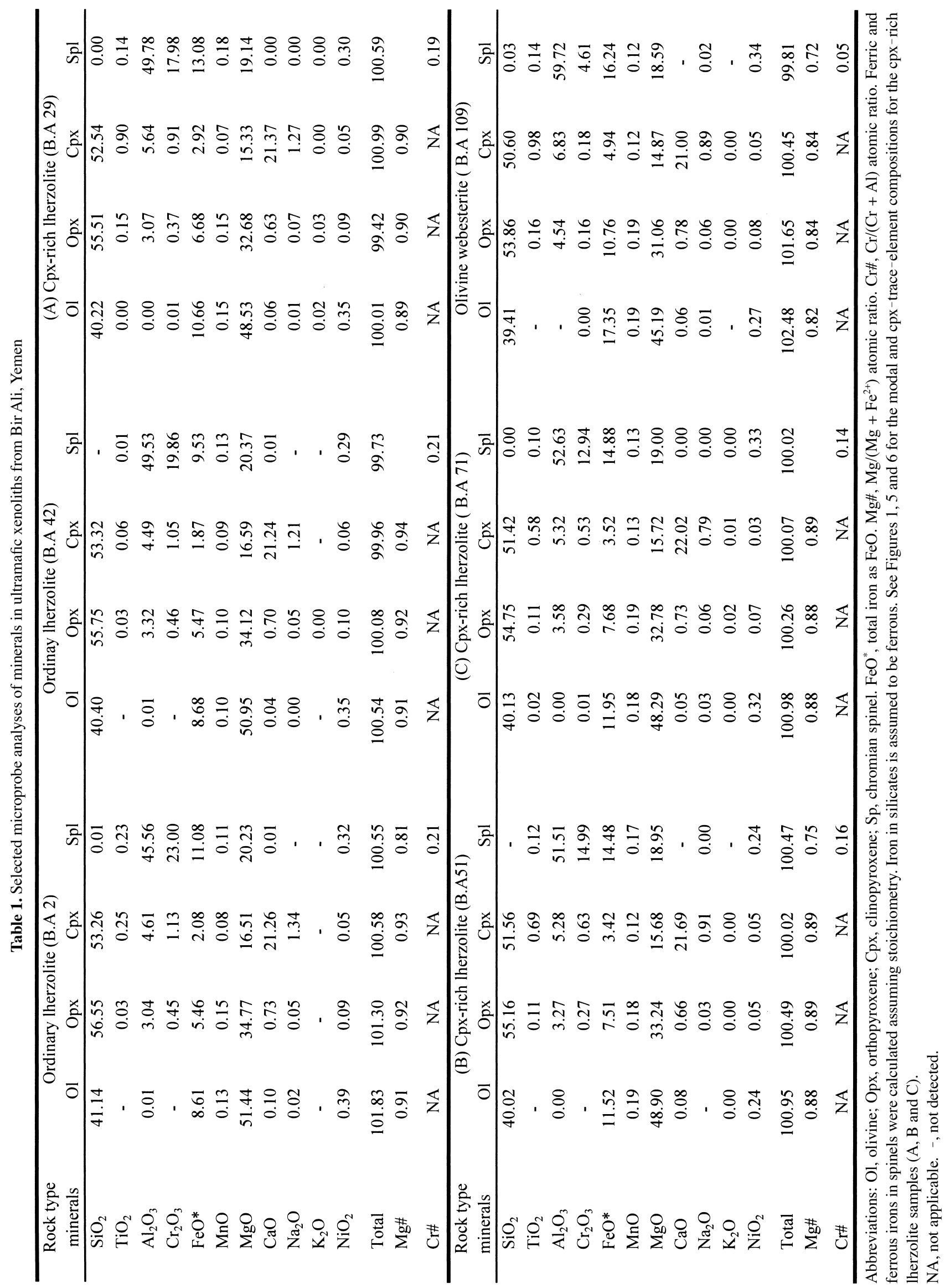




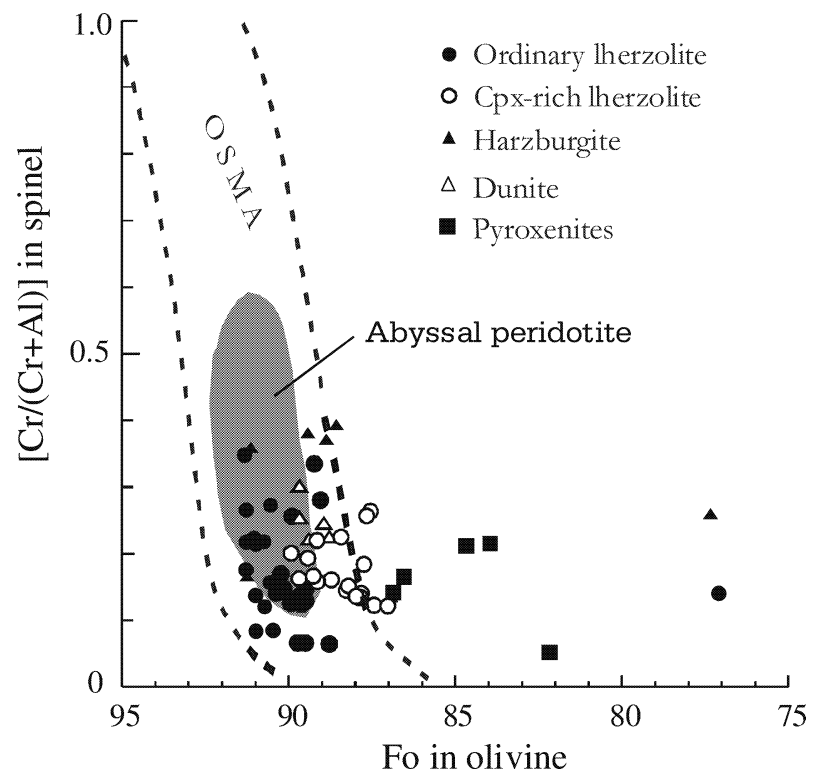

Figure 4. Relationships between Fo contents of olivine and $\mathrm{Cr} /(\mathrm{Cr}$ $+\mathrm{Al}$ ) atomic ratios of chromian spinel in ultramafic xenoliths from Bir Ali, Yemen. OSMA, olivine-spinel mantle array as a spinel peridotite residual trend (Arai, 1994). The field of abyssal peridotites are from Arai (1994). Note that the cpx-rich lherzolites have lower Fo contents than the ordinary lherzolites at a given $\mathrm{Cr} /(\mathrm{Cr}+\mathrm{Al})$ ratio of spinel.

well-developed triple-point junctions with approximately $120^{\circ}$ grain angles. Coarse olivine crystals $(>4 \mathrm{~mm})$ are kinked. Most of the cpx-rich lherzolites are fine-grained and exhibit protogranular textures having coarse grains of clinopyroxene with medium to small grains of olivine (Fig. 3B). Spinels show holly-leaf shapes (up to $2 \mathrm{~mm}$ ) in the cpx-rich lherzolites. Pyroxenes crystals do not show deformation or exsolution structure (Fig. 3B). Pyroxenites (websterite and olivine websterite) from Bir Ali are dominated by clinopyroxenes with minor amounts of orthpyroxene, olivine, and spinel. Some of the peridotite xenoliths contain melt pockets that consist of euhedral clinopyroxenes of pale grayish-green color.

\section{MINERAL CHEMISTRY}

Minerals were analysed for major elements by electron microprobe, and selected clinopyroxenes for trace elements by LA-ICP-MS at Kanazawa University. Selected microprobe analyses are listed in Table 1 . The Fo content of olivine varies continuously from 91 to 87 and the $\mathrm{Cr} \#$ of spinel varies from 0.36 to 0.0 . The ordinary lherzolites are plotted within the olivine-spinel mantle array (OSMA), a residual spinel peridotite field (Fig. 4). In contrast, some of the cpx-rich lherzolites are off the OSMA; they have slightly lower-Fo olivines than the ordinary lherzolites at a given $\mathrm{Cr} \#$ of spinel (Fig. 4). The $\mathrm{Mg} /(\mathrm{Mg}$

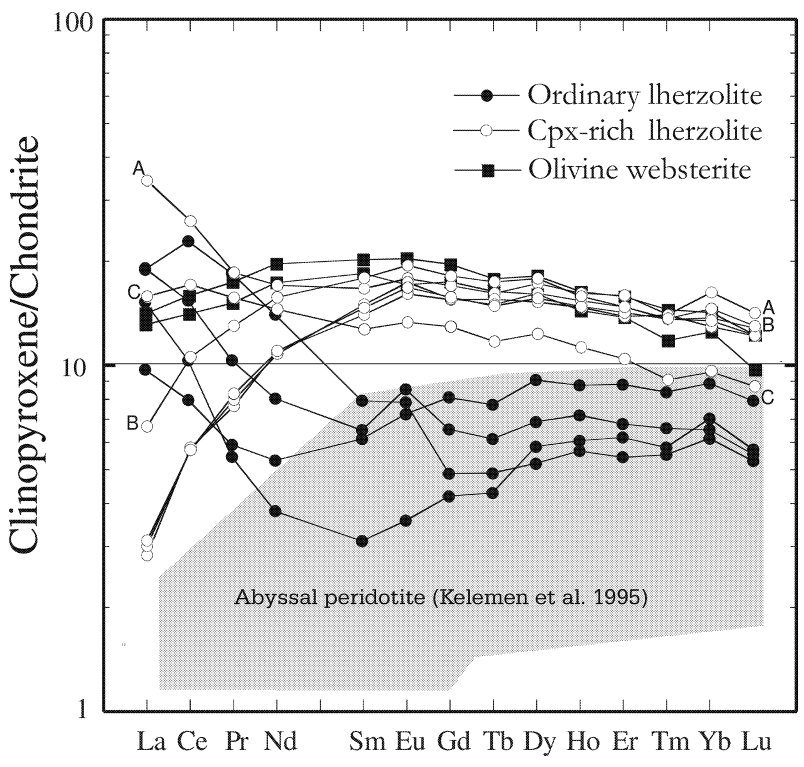

Figure 5. Chondrite-normalized REE patterns of clinopyroxenes in the ordinary lherzolites, $\mathrm{cpx}$-rich lherzolites and olivine websterites from Bir Ali, Yemen. Chondrite abundances after McDonough and Sun (1995). The field of abyssal peridotites is after Kelemen et al. (1995). Note the differences in REE characteristics between the ordinary lherzolites and cpx-rich ones. See Figure 2 and Table 1 for the typical three samples of cpx-rich lherzolite (A, B and C).

$+\mathrm{Fe}$ ) value of orthpyroxenes is almost equal to or slightly higher than that of coexisting olivines. Clinopyroxenes are higher in $\mathrm{TiO}_{2}$ and $\mathrm{Al}_{2} \mathrm{O}_{3}$ contents in the cpx-rich lherzolites than in the ordinary lherzolites (Table 1). Euhedral clinopyroxenes from melt pockets have lower $\mathrm{SiO}_{2}, \mathrm{Na}_{2} \mathrm{O}$, and higher $\mathrm{Al}_{2} \mathrm{O}_{3}, \mathrm{TiO}_{2}$ and $\mathrm{Cr}_{2} \mathrm{O}_{3}$ contents than the peridotite clinopyroxenes (Table 1 ).

We determined equilibration temperatures for some of the lherzolites using two-pyroxene thermometry of Wells (1977). The cpx-rich lherzolite and wehrlite have slightly lower equilibration temperatures $\left(876\right.$ to $\left.978{ }^{\circ} \mathrm{C}\right)$ than the ordinary lherzolites (990 to $1133{ }^{\circ} \mathrm{C}$ ).

Clinopyroxenes from the ordinary lherzolites show relatively low HREE contents, equivalent to abyssal lherzolites (Kelemen et al., 1995), and strong enrichment in LREE (Fig. 5). Clinopyroxenes in the cpx-rich lherzolites show high HREE contents than ordinary lherzolites and exhibit convex-upword patter. The LREE content is variable, however, some show enrichment as ordinary lherzolite, while others show depletion. Plotted together with other trace elements, $\mathrm{Sr}, \mathrm{Zr}$, Ti and $\mathrm{Y}$, negative anomalies are noted for $\mathrm{Y}, \mathrm{Ti}$, and $\mathrm{Zr}$, in the cpx-rich lherzolites and weaker than in the ordinary lherzolites (Fig. 6). Olivine websterites have similar patterns of clinopyroxenes with the cpx-rich lherzolites (Figs. 5 and 6). As expected, the ordinary lherzolites show a positive correlation between modal amounts and $\mathrm{Yb}$ content of clinopyroxenes. In con- 


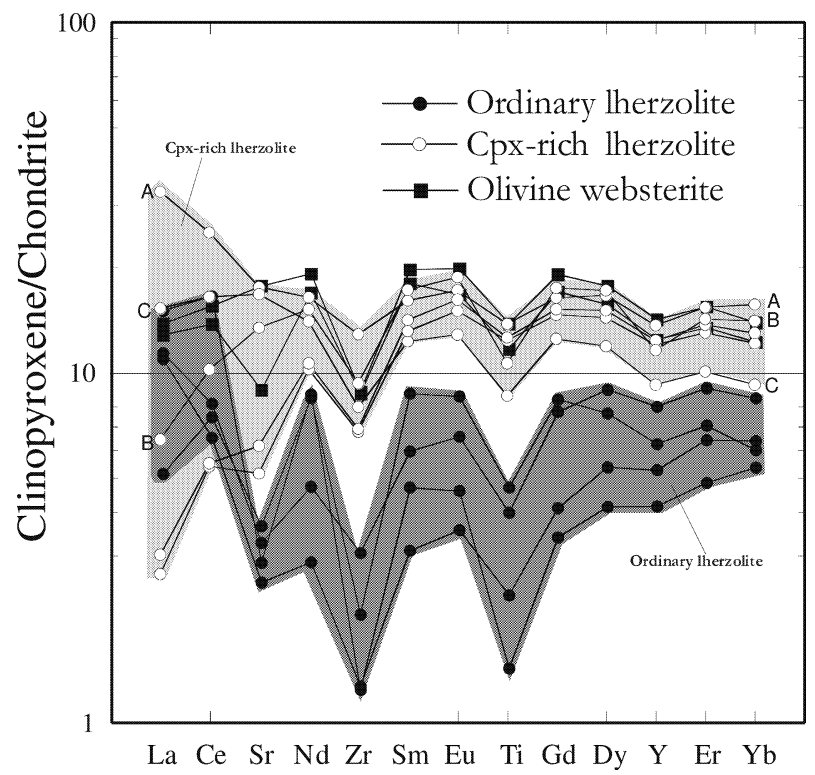

Figure 6. The same data as in Figure 5, plotted together with other trace elements, $\mathrm{Sr}, \mathrm{Zr}$, Ti and Y. Chondrite abundance data after McDonough and Sun (1995) were used.

trast, these parameters show a negative correlation in the cpx-rich lherzolites.

\section{DISCUSSION}

The cpx-rich lherzolites exhibit the modal and mineral chemical compositions that are not consistent to mantle residual origin (Figs. 2, 4 to 6 ). Their clinopyroxenes are overall enriched in REE, and they can be produced by metasomatic modification from mantle residue by reaction with some alkali basaltic melt. Alkali basaltic melts are strongly reactive to orthopyroxene at some low pressures, precipitating clinopyroxene and olivine (e.g., Shaw, 1999). The precipitation of clinopyroxene and olivine at the expense of orthopyroxene can produce clinopyroxene-rich lherzolites or even wehrlites. We could not find any textures to indicate this reaction in the cpx-rich lherzolite, probably due to textural modification during recrystallization. Some of the olivine websterites from Bir Ali are possibly cumulates or higher-degree metasomatic products from such alkali basalts. The involved alkaline basalt was akin in chemistry to but older than the host alkali olivine basalt. Clinopyroxenes in the cpx-rich lherzolites from Bir Ali have a hybrid character between the olivine websterite and some depleted peridotite (Fig. 5), being formed by mixing of two kinds of clinopyroxene, residual one in the protolith and the metasomatically added one.

Fabriès et al. (1988) made a similar interpretation for solid-intrusive cpx-rich lherzolites from the northeastern
Pyrénées. Such cpx-rich lherzolites are commonly found as xenoliths from continental rift zones (e.g., WittEickschen and Kramm, 1998; Xu et al., 2002), as well as a solid-intrusive peridotite from rifted continental margins, such as Galicia Bank, off west Iberia (Chazot et al., 2005). Clinopyroxenes in the cpx-rich lherzolites from these localities (Xu et al., 2002; Chazot et al., 2005) demonstrate similar REE characteristics to those from Bir Ali. They may be one of common constituents of subcontinental lithosphere.

The lithospheric mantle beneath Bir Ali is mainly composed of the ordinary lherzolites and cpx-rich lherzolites. Equilibrium temperatures are systematically lower for the latter than for the former, indicating the shallowest distribution of the latter in the lithospheric mantle beneath Bir Ali, Yemen. The strong enrichment of some clinopyroxenes in LREE (Fig. 5) may indicate metasomatism after formation of lherzolitic restites, which are protolith of the ordinary lherzolites, and the cpx-rich lherzolites. Alkali basaltic magmatism is active in the continental rift environment and often serves as a carrier of mantle xenoliths. The mantle metasomatism caused by alkali basalt magma invasion commonly occurs beneath the rift zone like the Afar-Arabian rift.

\section{CONCLUSIONS}

The cpx-rich lherzolite xenoliths from Bir Ali, Yemen, are representative of the shallow portion of lithospheric mantle at the rifted continental margin of the Arabian Peninsula. They have high clinopyroxene/orthopyroxene ratios $(>1)$ and demonstrate enriched mineral chemistry, being clearly different from mantle residual peridotites. They were most probably produced by reaction between residual peridotites and an alkali basaltic melt, which precipitated clinopyroxene and olivine at the expense of residual orthopyroxene. Such clinopyroxene-rich lherzolites and wehrlites are common to the lithospheric mantle from continental rift zones or rifted continental margins.

\section{ACKNOWLEDGMENTS}

We are indebted to Dr. Akihiro Tamura and Mr. Yoshito Ishida, Department of Earth Science, Kanazawa University, Japan, for assistance during analysis with microprobe and LA-ICP-MS. Also we are grateful to our friends in Department of Earth Science, Taiz University, Yemen, for their help to collect xenoliths samples. Critical comments of Prof. Masaaki Obata and Dr. Natsue Abe were helpful in revision of the previous manuscript. 


\section{REFERENCES}

Arai, S. (1994) Characterization of spinel peridotites by olivinespinel compositional relationships: review and interpretation. Chemical Geology, 113, 191-204.

Baker, J.A., Chazot, G., Menzies, M.A. and Thirlwall, M.F. (2002) lithospheric mantle beneath Arabia: A Pan-African protolith modified by Afar and older plumes, rather than a source for continental flood volcanism. Geological Society of America Special Paper, 362, 65-80.

Beard, A.D., Downes, H. and Vetrin, V.R. (2006) Depletion and enrichment processes in the lithospheric mantle the Kola Peninsula (Russia): Evidence from spinel lherzolite and wehrlite xenoliths. Lithos, in press.

Chazot, G., Menzies, M.A. and Harte, B. (1996a) Determination of partion coefficients between apatite, clinopyroxene, amphibole and melt in natural spinels lherzolites from Yemen: implications for wet melting of the lithospheric mantle. Geochimica et Cosmochimca Acta, 60, 423-437.

Chazot, G., Menzies, M.A. and Harte, B. (1996b) Silicate glasses in spinel lherzolites from Yemen: origin and chemical compositions. Chemical Geology, 134, 159-179.

Chazot, G., Lowry D., Menzies, M.A. and Mattey, D.P. (1997) Oxygen isotopic composition of megacrysts and minerals in hydrous and anhydrous mantle xenoliths from Yemen and Nunivak Island. Contributions to Mineralogy and Petrology, 61, 161-169.

Chazot, G., Charpentier, S., Kornprobst, J. and Vannucci, R. (2005) lithospheric Mantle evolution during continental break-up: The west Iberia Non-volcanic Passive margin. Journal of Petrology, 46, 2527-2568.

Dawson, J.B. (2002) Metasomatism and partial melting in uppermantle peridotites xenoliths from the Lashaine Volcano, Northern Tanzania. Journal of Petrology, 43, 1749-1777.

Fariès, J., Bodinier, J.L., Dupuy. D., Lorand, J.P. and Benkerrou, C. (1989) Evidence for modal metasomatism in the orogenic spinel lherzolite body from Caussou (Northeastern Pyrenees, France). Journal of Petrology, 30, 199-228.

Griffin, W.L., Shee, S.R., Ryan, C.G., Win, T.T. and Wyatt, B.A.
(1999) Harzburgite to lherzolite and back again: metasomatic processes in ultramafic xenoliths from Wesselton kimberlite, Kimberley, South Africa. Contributions to Mineralogy and Petrology, 134, 232-250.

Kelemen, P.B., Shmizu, N. and Salters, V.J.M. (1995) Extraction of mid-ocean ridge basalt from the upwelling mantle by focused melt in dunite channels. Nature, 375, 747-53.

McDonough, W.F. and Sun, S.- ${ }^{-s}$. (1995) The composition of the Earth, Chemical Geology. 120, 223-253.

Ministry of Oil and Minerals, Department of Geology and Mineral Exploration (1982-1986) Geological survey and prospecting in the Habban-Mukalla area, southern part of Yemen. pp. 303, Final Report,Yeman.

Shaw, C.S.J. (1999) Dissolution of orthpyroxene in basanitic magma between 0.4 and $2 \mathrm{GPa}$ : further implications for the origin of $\mathrm{Si}$-rich alkaline glass inclusions in mantle xenoliths. Contributions to Mineralogy and Petrology, 135, 114132.

Wells, P.R.A. (1977) Pyroxene thermometry in simple and complex systems. Contributions to Mineralogy and Petrology, 62, 129-139.

White, R. and McKenzie, D. (1989) magmatism at rift zones: The generation of volcanic continental and flood basalts. Journal of Geophysical Research, 94, 685-729.

Witt-Eickschen, G. and Kramm, U. (1998) Evidence for the multiple stage evolution of the subcontinental lithospheric mantle beneath the Eifel (Germany) from pyroxenite and composite pyroxenite/peridotite xenoliths. Contributions to Mineralogy and Petrology, 131, 258-272.

Xu Y.G., Menzies, M.A. and Thirlwall, M.F. (2002) Reactive harzburgite from Huinan, NE China: products of the lithosphere-asthenosphere interaction during lithospheric thinning. Geochimica et Cosmochimca Acta, 67, 487-505.

Manuscript received August 26, 2006

Manuscript accepted December 15, 2006

Published online February 17, 2007

Manuscript handled by Masaaki Obata 